ARTICLE

\title{
Comparative studies on nutritional composition of captive and wild southern hake Merluccius australis broodstocks
}

\author{
Estudios comparativos de la composición nutricional de reproductores cautivos y \\ silvestres de merluza austral Merluccius australis
}

\author{
Edison Serrano $^{1 *}$, Robert Simpfendorfer ${ }^{2}$, Jaime Paillaman ${ }^{3}$ and Juan Carlos Sánchez ${ }^{3}$ \\ ${ }^{1}$ Centro de Investigaciones Costeras, Universidad de Atacama, Copayapu 485, Copiapó, Chile \\ ${ }^{2}$ Departamento de Acuicultura y Recursos Agroalimentarios, Universidad de los Lagos, Avenida Fuchslocher 1305, Osorno, Chile \\ ${ }^{3}$ Estación Experimental Quillaipe, Unidad de Gestión Tecnológica, Área de Alimentos y Biotecnología, Fundación Chile, Puerto Montt, \\ Chile \\ *Corresponding author: edison.serrano@uda.cl
}

\begin{abstract}
Resumen.- La composición proximal, aminoácidos y perfil de ácidos grasos fueron determinados en el cuerpo entero de merluza austral (Merluccius australis) mantenidas bajo condiciones de cautiverio y silvestres, con el fin de evaluar las diferencias en el contenido de nutrientes debido a la calidad nutricional de los alimentos consumidos durante el acondicionamiento de reproductores de esta especie. La composición corporal de merluza austral no mostró diferencias significativas en la materia seca, proteína o contenido de cenizas entre los dos grupos estudiados. Por el contrario, el contenido de lípidos fue significativamente mayor en el cuerpo entero de los peces cautivos en comparación con los peces silvestres. Asimismo, la concentración de los ácidos linoleico, docosahexaenoico y eicosapentaenoico, mostró significativamente niveles más altos en la merluza cultivada que en la merluza silvestres. Las concentraciones de la treonina y la taurina fueron diferentes entre los tratamientos, donde la treonina fue mayor en la merluza silvestre, mientras que la concentración de taurina fue mayor en la merluza cautiva, no así para el resto de los aminoácidos. Los resultados de este estudio comparativo proporcionan una mejor comprensión de los efectos de la alimentación suplementaria utilizada actualmente para aclimatar y mantener en cautiverio reproductores de merluza austral.
\end{abstract}

Palabras clave: Merluza austral, Merluccius australis, composición cuerpo completo, amino ácidos, ácidos grasos, acuicultura

\begin{abstract}
The proximal composition, amino acids and fatty acid profile were determined in whole body of wild and captive southern hake (Merluccius australis) in order to evaluate the differences in nutrients content due to the nutritional quality of the feed consumed during broodstock conditioning of this species. Body composition of southern hake did not show significant differences in dry matter, protein or ash content between both studied groups. Conversely, lipid content was significantly higher in the whole body of captive fish compared to the wild fish. In addition, the concentration of linoleic, docosahexaenoic and eicosapentaenoic acids, showed significantly higher level in captive hake than the wild hake. Amino acids concentrations did not vary between fish, except threonine and taurine. Threonine concentration was higher in wild hake whereas taurine concentration was higher in captive hake. The results of this comparative study provide a better understanding of the effects of supplemented feed currently used to acclimate and maintain in captivity southern hake broodstock.
\end{abstract}

Key words: Chilean Southern hake, Merluccius australis, whole body composition, amino acid, fatty acid, aquaculture

\section{INTRODUCTION}

Chilean aquaculture is poorly diversified and reliant mostly on the farming of salmonids (Wurmann 2007, Niklitschek et al. 2013). Nevertheless, the economic success of the salmon farming industry has attracted the interest from the private sector, academic and government to develop technology for growing native species of high commercial value (Silva 2011). Among the native species considered to diversify Chilean aquaculture, Southern hake (Merluccius australis) has been selected as one of the important candidate species for farming (Bustos \& Landaeta 2005, Bustos et al. 2007a).

Southern hake is a demersal species distributed in Chilean, Argentinean and New Zealand waters (Bustos et al. 2007b). This fish species reaches an average length of $65 \mathrm{~cm}$ and lives around 30 years (Aguayo-Hernández 1995, Colman 1995, Tingley et al. 1995). In Chilean coast, $M$. australis feeds on squids, fishes, crustaceans and benthonic organisms (Aguayo-Hernández 1995). 
Southern hake is amongst the highest valued white fish in the world, being demanded by local and international markets (Sylvia 1995). However, the fisheries have been diminished in recent years, which have triggered a considerable number of biological scientific investigations in order to development farming technology for this specie (Bustos \& Landaeta 2005, Bustos et al. 2007a,b; Silva 2011). Even though there is an advanced understanding of the biology of southern hake, there still some relevant questions concerning their nutrition requirements and the effect of the feed used during broodstock conditioning.

Several researches addressed the differences in chemical body composition between farmed and wild fish (Ackman \& Takeuchi 1986, Alasalvar et al. 2002, Yildiz et al. 2008). In general, the chemical composition of fish can be influenced by intrinsic (e.g., fish species, size, sex and age, etc.) and extrinsic factors (e.g., diet and rearing conditions, etc.) (Børrensen 1992, Shearer 1994). In farmed fish, compound diets that provide various nutrients represent one of the major determining factors affected the flesh composition, especially the fatty acid profiles (Ackman \& Takeuchi 1986, Yildiz et al. 2008). During captivity, hake species have reported to be fed a semi-moist diet composed of fishmeal (35\%), fish (30\%), squid (17\%) mussel (18\%) and vitamin premix $\left(6 \mathrm{mg} \mathrm{kg}^{-1}\right)$, and supplemented with thawed dead fish (mainly sardine and sand eel (Iglesias et al. 2010, Sánchez et al. 2012).

The chemical compositions of wild fish, on the other hand, are affected by the ocean environmental conditions, which regulate the nutrients availability (Guisande et al. 1998, Bustos et al. 2011). Nutritional composition and type of preys can vary considerably during the year, consequently, affecting the nutritional status and body composition of the fish (Paya 1992, Arkhipkin et al. 2003, Bustos et al. 2011).

The present study compared the main chemical composition differences between wild and captive southern hake (M. australis) in order to evaluate the effects of supplemented feed currently used to acclimate and maintain in captivity broodstock of this native fish species.

\section{Materials AND METHODS}

\section{FisH SAMPLING}

Three individuals of $2.60 \pm 0.35 \mathrm{~kg}$ (mean body length $74.67 \pm 5.13 \mathrm{~cm}$ and mean condition factor $0.63 \pm 0.06$ ) were randomly collected from the broodstock conditioning facilities at Fundación Chile Quillaipe (Puerto Montt, Chile). Originally, these fish were captured in the inland waters of the Reloncavi Sound in the Lagos Region $\left(41^{\circ} 31^{\prime} \mathrm{S}, 72^{\circ} 44^{\prime} \mathrm{W}\right)$ and then kept in captivity for 2 years. The fish were reared under low-density conditions (about $3 \mathrm{~kg} \mathrm{~m}^{-3}$ ) in two $30,000 \mathrm{~L}$ circular fibreglass tanks supplied with seawater $\left(9.0 \pm 1.0^{\circ} \mathrm{C}\right.$; flow rate $\left.15 \mathrm{~L} \mathrm{~min}^{-1}\right)$. Each fish was fed once a day with a commercial moist feed based on Broodstock Dry Mix (Skretting Chile) ${ }^{1}$ at $2 \%$ of their body weight and supplemented with 100 grams of squids and sardines. The formulation and proximate composition of the commercial feed are shown in Table 1.

Similarly, another six individuals of $2.58 \pm 0.25 \mathrm{~kg}$ (mean body length $73.82 \pm 2.18 \mathrm{~cm}$ and mean condition factor $0.62 \pm 0.09$ ) were captured using long line fishing gear during winter at the same location where captive fish were early caught.

After being collected, each fish was ground completely, homogenized and stored for later analysis.

Table 1. Formulation and proximal composition of commercial moist feed / Formulación y composición proximal de alimento comercial húmedo

\begin{tabular}{lc}
\hline & $\begin{array}{c}\text { Commercial } \\
\text { broodstock feed }\end{array}$ \\
\hline Ingredients (g $100 \mathrm{~g}^{-1}$ dry weight) & \\
Broodstock dry mix* & 46.0 \\
Fish oil & 5.0 \\
Binder (Gely Gum 7277) & 2.0 \\
Sodium chloride & 3.7 \\
Water & 43.3 \\
Proximate composition (\% dry weight) & \\
Moisture & 7.2 \\
Protein & 61.7 \\
Lipid & 16.4 \\
Ash & 12.3 \\
\hline
\end{tabular}

*Composition: Protein 60\%, Lipids $6 \%$, Carbohydrates $11 \%$, Ash $15 \%$ and Moisture $8 \%$ 


\section{Chemical analysis}

Fish carcass were analyses for dry matter, ash, fat, protein, phosphorus, amino acids, fatty acids and gross energy content according to the methods of AOAC (2002). Dry matter was determined by drying at $105{ }^{\circ} \mathrm{C}$ overnight. Protein was determined by Kjeldahl-N*6.25 (Notice Jinan Hanon Instruments Co., Ltd). Fat in fish was determined using $\mathrm{HCl}$ hydrolysis followed by diethyl ether extraction. Ash was determined by combustion at $550{ }^{\circ} \mathrm{C}$ for $16 \mathrm{~h}$.

Amino acid compositions were determined by highperformance liquid chromatography (HPLC), following acid hydrolysis of samples. The acid hydrolysis did not enable the determination of the levels of tryptophan in the fish samples.

Lipids were extracted with a mix of chloroform and methanol (2:1) (Folch et al. 1957). Methyl esters from fatty acids obtained from lipids were prepared following the method proposed by Morrison \& Smith (1964). Fatty acids were separated by gas-liquid chromatography (Hewlett Packard 5890 series II Plus, Wilmington, USA) using a 30 x $0.25 \mathrm{~mm}$ id x $0.25 \mu \mathrm{m}$ capillary column HP-225 (Hewlett Packard, Wilmington, USA). Nitrogen was used as carrier gas. Fatty acids were identified by comparison to a well characterized standard such as GLC 462 (Nu-Chek Prep, Elysian, USA). The fatty acids from the whole-body fish were expressed as dry basis.

\section{STATISTICAL ANALYSIS}

Data was analyzed by student Test. Arcsine square root transformations of percentage data were conducted to achieve homogeneity of variance. All the statistical analyses were performed using GraphPad Prism Statistics software (GraphPad, San Diego, CA, USA).

\section{RESULTS}

The results of proximate, fatty acids and amino acids analysis of cultured and wild southern hake are showed in Table 2, 3 and 4, respectively.

Body composition of southern hake did not show meaningful differences in dry matter, protein, or ash content between both studied groups $(P>0.05)$. Nevertheless, lipid content of captive fish was significantly higher $(P<0.05)$, and dry matter content was significantly lower $(P<0.05)$ when compared to wild fish.

Total saturated fatty acids (SAFAs) displayed significant differences between both fish groups $(P<0.05)$. Palmitic acid (C16:0) was the most common SAFAs and its concentration was significantly higher in captive southern hake than in wild southern hake. Stearic acid (18:0) and heptadecanoic acid (17:0) were the secondary SAFAs for farmed and wild fish, respectively.
Table 2. Proximate composition ( $\mathrm{g} 100 \mathrm{~g}^{-1}$ wet weight) in whole body of wild and captive southern hake / Composición proximal (g $100 \mathrm{~g}^{-1}$ peso húmedo) del cuerpo completo de merluza austral cautiva y silvestre

\begin{tabular}{lcc}
\hline & \multicolumn{2}{c}{ Merluccius australis } \\
\cline { 2 - 3 } & Wild & Captive \\
\hline Moisture & $75.04 \pm 0.60^{\mathrm{a}}$ & $72.65 \pm 0.90^{\mathrm{b}}$ \\
Protein & $17.68 \pm 0.30$ & $16.95 \pm 1.09$ \\
Lipid & $4.36 \pm 0.91^{\mathrm{a}}$ & $7.70 \pm 1.11^{\mathrm{b}}$ \\
Ash & $2.92 \pm 0.12$ & $2.70 \pm 0.47$ \\
\hline
\end{tabular}

Values are mean $\pm \operatorname{SE}(n=3$ captive fish and $n=6$ wild fish), and within same column with different superscripts are statistically different at $P<0.05$

Table 3. Fatty acid composition ( $\mathrm{g} \mathrm{kg}^{-1}$ wet weight) in whole body of wild and farmed southern hake / Composición de ácidos grasos ( $g$ $\mathrm{kg}^{-1}$ peso húmedo) del cuerpo completo de merluza austral cultivada y silvestre

\begin{tabular}{lcc}
\hline & \multicolumn{2}{c}{ Merluccius australis } \\
\cline { 2 - 3 } & Wild & Captive \\
\hline Total SAFA & $11.28 \pm 3.79^{\mathrm{a}}$ & $20.43 \pm 5.82^{\mathrm{b}}$ \\
Palmitic acid & $8.91 \pm 2.89^{\mathrm{a}}$ & $15.83 \pm 4.17^{\mathrm{b}}$ \\
Total MUFA & $18.14 \pm 4.51^{\mathrm{a}}$ & $28.74 \pm 4.28^{\mathrm{b}}$ \\
Oleic acid & $11.08 \pm 2.79^{\mathrm{a}}$ & $15.58 \pm 1.89^{\mathrm{b}}$ \\
Palmitoleic acid & $4.09 \pm 0.81^{\mathrm{a}}$ & $6.52 \pm 1.40^{\mathrm{b}}$ \\
Total PUFA & $14.33 \pm 3.47^{\mathrm{a}}$ & $28.72 \pm 2.96^{\mathrm{b}}$ \\
Linoleic acid & $0.50 \pm 0.12^{\mathrm{a}}$ & $1.95 \pm 1.23^{\mathrm{b}}$ \\
Linolenic acid & $0.32 \pm 0.25$ & $0.86 \pm 0.44$ \\
DHA & $5.63 \pm 1.42^{\mathrm{a}}$ & $10.50 \pm 1.21^{\mathrm{b}}$ \\
EPA & $5.59 \pm 1.23^{\mathrm{a}}$ & $10.77 \pm 3.39^{\mathrm{b}}$ \\
ARA & $0.37 \pm 0.25$ & $0.18 \pm 0.06$ \\
\hline
\end{tabular}

Values are mean $\pm \operatorname{SE}(\mathrm{n}=3$ captive fish and $\mathrm{n}=6$ wild fish), and within same column with different superscripts are statistically different at $P<0.05$

Captive southern hake had higher $(P<0.05)$ total monounsaturated fatty acids (MUFAs) and total polyunsaturated fatty acids (PUFAs) than that of wild fish. Among MUFAs, oleic acid (C18:1n-9), the major MUFAs in both groups, was higher $(P<0.05)$ in wild fish than captive fish. Similarly, palmitoleic acid (16:1n-7), the second MUFAs in both groups, was higher $(P<0.05)$ in wild fish than in captive fish.

Regarding PUFAs, wild and captive southern hake contained a larger proportion of n-3 PUFAs than n-6 PUFAs. Concentration of linoleic acid (18:2n-6) showed significantly lower level $(P<0.05)$ in wild hake than in captive hake. Linoleic acid in wild hake was found in 
Table 4. Amino acid composition ( $\mathrm{g} \mathrm{kg}^{-1}$ wet weight) in whole body of wild and farmed southern hake / Composición de aminoacidos (g $\mathrm{kg}^{-1}$ peso húmedo) del cuerpo completo de merluza austral cultivada y silvestre

\begin{tabular}{|c|c|c|}
\hline & \multicolumn{2}{|c|}{ Merluccius australis } \\
\hline & Wild & Captive \\
\hline \multicolumn{3}{|c|}{ Essential amino acid (EAA) } \\
\hline Arginine & $15.25 \pm 1.10$ & $15.87 \pm 1.30$ \\
\hline Histidine & $5.72 \pm 0.38$ & $5.80 \pm 0.79$ \\
\hline Isoleucine & $6.42 \pm 0.41$ & $6.43 \pm 0.06$ \\
\hline Leucine & $9.11 \pm 0.36$ & $8.97 \pm 0.15$ \\
\hline Lysine & $8.90 \pm 0.68$ & $8.97 \pm 0.25$ \\
\hline Methionine & $10.23 \pm 1.35$ & $10.87 \pm 1.11$ \\
\hline Phenylalanine & $5.35 \pm 0.34$ & $5.33 \pm 0.21$ \\
\hline Threonine & $7.10 \pm 0.16^{\mathrm{a}}$ & $6.37 \pm 0.45^{\mathrm{b}}$ \\
\hline Tryptophan & $1.15 \pm 0.07$ & $1.00 \pm 0.10$ \\
\hline Valine & $2.55 \pm 0.13$ & $2.57 \pm 0.06$ \\
\hline \multicolumn{3}{|c|}{ Non-essential amino acids (NEAA) } \\
\hline Alanine & $6.97 \pm 0.55$ & $7.03 \pm 0.87$ \\
\hline Aspartic acid & $14.58 \pm 0.69$ & $14.27 \pm 0.57$ \\
\hline Cysteine & $2.86 \pm 1.22$ & $2.40 \pm 0.70$ \\
\hline Hydroxyproline & $5.09 \pm 0.80$ & $5.13 \pm 1.46$ \\
\hline Glutamic acid & $17.67 \pm 0.87$ & $17.53 \pm 1.10$ \\
\hline Glycine & $6.68 \pm 0.81$ & $7.37 \pm 1.66$ \\
\hline Proline & $9.25 \pm 0.83$ & $9.67 \pm 1.42$ \\
\hline Serine & $12.18 \pm 0.64$ & $11.03 \pm 1.05$ \\
\hline Taurine & $0.22 \pm 0.03^{\mathrm{a}}$ & $0.33 \pm 0.06^{b}$ \\
\hline Tyrosine & $3.18 \pm 0.12$ & $3.10 \pm 0.10$ \\
\hline
\end{tabular}

concentrations of $0.50 \pm 0.12 \mathrm{~g} \mathrm{~kg}^{-1}$ while in captivity hake concentration was $1.95 \pm 1.23 \mathrm{~g} \mathrm{~kg}^{-1}$. In contrast, the levels of linolenic acid (18:3n-3) exhibited no significant difference between the two groups. The concentration of linolenic acid was $0.32 \pm 0.25 \mathrm{~g} \mathrm{~kg}^{-1}$ in wild hake whereas in captive hake was $0.86 \pm 0.44 \mathrm{~g} \mathrm{~kg}^{-1}$.

Docosahexaenoic acid (DHA) presented significant differences $(P<0.05)$ between both groups of fish. The concentration of DHA in wild hake was $5.63 \pm$ $1.42 \mathrm{~g} \mathrm{~kg}^{-1}$ and in captive hake was $10.50 \pm 1.21 \mathrm{~g} \mathrm{~kg}^{-1}$. Eicosapentaenoic (EPA) also showed significant differences $(P<0.05)$ between both groups. The concentration of EPA was $5.59 \pm 1.23 \mathrm{~g} \mathrm{~kg}^{-1}$ in wild hake whereas in captive hake was $10.77 \pm 3.39 \mathrm{~g} \mathrm{~kg}^{-1}$. Conversely, the content of arachidonic acid (ARA) showed no significant difference $(P>0.05)$ between groups. The concentration of ARA in wild hake was $0.37 \pm 0.25 \mathrm{~g} \mathrm{~kg}^{-1}$ and in captive hake was $0.18 \pm 0.06 \mathrm{~g} \mathrm{~kg}^{-1}$.

Amino acids concentrations did not vary between fish, except threonine and taurine. Threonine concentration was higher $(P<0.05)$ in wild hake $\left(7.10 \pm 0.16 \mathrm{~g} \mathrm{~kg}^{-1}\right)$ when compared to captive hake $\left(6.37 \pm 0.45 \mathrm{~g} \mathrm{~kg}^{-1}\right)$, whereas taurine concentration was higher $(P<0.05)$ in captive hake $\left(0.33 \pm 0.06 \mathrm{~g} \mathrm{~kg}^{-1}\right)$ than wild hake $\left(0.22 \pm 0.03 \mathrm{~g} \mathrm{~kg}^{-1}\right)$.

Methionine, lysine, and leucine were three highest essential amino acid (EAA), while glutamic acid, aspartic acid and serine constituted the highest non-essential amino acid (NEAA) in both captive and wild southern hake.

\section{Discussion}

The results achieved in this study prove that feeding southern hake intensively with supplemented feed during captivity did not lead to significant changes in the proximate composition of whole body as compared to wild fish, except lipid content which increased.

Similar findings related to an increase of muscle fat content in farmed fish as compared to wild fish have been reported in Oncorhynchus mykiss (Fallah et al. 2011), Salmo salar (Johnston et al. 2006), Esox lucius (Jankowska et al. 2008), Solea senegalensis (Norambuena et al. 2012), Sparus aurata (Sağglık et al. 2003), Perca flavescens (Gonzalez et al. 2006) Leiocassis longirostris (Wang et al. 2012) and Dicentrarchus labrax (Alasalvar et al. 2002) as result of the application of commercial feed.

In accordance with the above, the difference in lipid composition found in the present study could be attributed to the effect of the high energy feed used during conditioning of southern hake to captivity, which has increment fat storage capacity of muscle and liver tissues. In the wild, southern hake feed on small amounts of food (mainly crustacean and other fish) over many hours and expend a large amount of energy searching and capturing these preys (Aguayo-Hernández 1995, Colman 1995). Therefore, feeding regimen and food nutritional value utilized in farming condition affect the normal status of lipid stored in adipose tissue (Shearer 1994).

The fatty acid profile of the stored lipid was different between the groups. The total content of saturated fatty acids, monounsaturated and polyunsaturated showed a higher concentration in the farmed southern hake than in the wild southern hake. Studies on other carnivorous fish species have shown higher levels of saturated and polyunsaturated fatty acids in wild specimens, whereas farmed fish showed a higher content of monounsaturated fatty acids (Alasalvar et al. 2002, Jankowska et al. 2008, Fuentes et al. 2010, Norambuena et al. 2012). 
The concentrations of nutritionally important fatty acids, linoleic acid, DHA and EPA observed significant higher levels in farmed southern hake in comparison to wild hake. Meanwhile, ARA concentration showed no significant differences between the groups. These findings are somewhat in disagreement with data from previous studies on E. lucius (Jankowska et al. 2008), S. senegalensis (Norambuena et al. 2012) and D. labrax (Fuentes et al. 2010).

Considering the fact that fatty acid composition in fish body is directly related to the fatty acid profile in the diets (Glencross 2009), the differences in fatty acids between wild and farmed southern hake found in our study could be explained by the inclusion of high levels of fish oil and fishmeal as feed ingredients for farmed southern hake.

In relation to the amino acid content of southern hake whole body, analyses showed that only taurine and threonine recorded significant differences between groups. Taurine concentration reported in wild $M$. australis a lower value relative to farmed fish. These differences may be explained due to the utilization of fishmeal, which contain high levels of taurine (Espe et al. 2012), as a main ingredient in the diet used for feeding $M$. australis in captivity. Conversely, a comparative study between wild and farmed D. labrax showed that taurine is present in lower levels in farmed sea bass, owing to low fishmeal within commercial diet for this fish species (Fuentes et al. 2010).

On the other hand, threonine concentration reported in wild $M$. australis a higher value relative to farmed $M$. australis. Similar results have been reported regarding the reductive effect of farming practice on the concentration of this aminoacids in different fish species. The studies carried out on D. labrax by Fuentes et al. (2010) and on Pseudobagrus ussuriensis by Wang et al. (2012), found a trend towards a lower concentration of threonine in farmed fish compared to wild fish.

The whole-body concentration of threonine is increased in response to the gradient increase in dietary threonine levels (Grisdale-Helland et al. 2013), therefore the high concentration of this amino acid in our experiment is related to nutritional quality of feed used in the study.

To conclude, the nutritional composition of the diets supplied to southern hake in captivity is the main cause of the difference in lipid, amino acids, and fatty acids composition with wild fish. Nevertheless, these differences are not necessarily negative since high concentration of EPA and DHA in broodstock diet have been identified as major dietary factors that determine successful reproduction and survival of offspring (Izquierdo et al. 2001). Future work is required to evaluate the effect of the diet consumed by southern hake in captivity on reproductive and growth performances.

\section{ACKNOWLEDGMENTS}

The authors want to thank Karla Castro at Universidad de Los Lagos for skillful technical assistance during the experiment. This research was supported by funding from National Commission for Scientific and Technological Research (CONICYT) in the frame of the project FONDEF DA09I 1001.

\section{LITERATURE CITED}

Ackman RG \& T Takeuchi. 1986. Comparison of fatty acids and lipids of smolting hatchery-fed and wild Atlantic salmon Salmo salar. Lipids 21: 117-120.

Aguayo-Hernández M. 1995. Biology and fisheries of Chilean hakes (M. gayi and M. australis). In: Alheit J \& TJ Pitcher (eds). Hake: Fisheries, ecology, and markets, pp. 305-337. Chapman and Hall, London.

Alasalvar C, KDA Taylor, E Zubcov, F Shahidi \& M Alexis. 2002. Differentiation of cultured and wild sea bass (Dicentrarchus labrax): total lipid content, fatty acid and trace mineral composition. Food Chemistry 79: 145-150.

AOAC. 2002. Official methods of analysis of the association of analytical chemists, $1085 \mathrm{pp}$. Association of Official Analytical Chemists, Washington.

Arkhipkin AI, DAJ Middleton, JM Portela \& JM Bellido. 2003. Alternative usage of common feeding grounds by large predators: the case of two hakes (Merluccius hubbsi and M. australis) in the southwest Atlantic. Aquatic Living Resources 16: 487-500.

Borrensen T. 1992. Quality aspects of wild and reared fish. In: Huss HH, M Jacobsen \& J Liston (eds). Quality assurance in the food industry, pp.1-17. Elsevier, Amsterdam.

Bustos CA \& MF Landaeta. 2005. Desarrollo de huevos y larvas tempranas de la merluza del sur, Merluccius australis, cultivados bajo condiciones de laboratorio. Gayana 69: 402-408.

Bustos CA, MF Landaeta, E Bay-Schmith, R Lewis \& X Moraga. 2007a. Effects of temperature and lipid droplet adherence on mortality of hatchery-reared southern hake Merluccius australis larvae. Aquaculture 270: 535-540.

Bustos CA, F Balbontín \& MF Landaeta. 2007b. Spawning of the southern hake Merluccius australis (Pisces: Merlucciidae) in Chilean fjords. Fisheries Research 83: 23-32.

Bustos CA, MF Landaeta \& F Balbontin. 2011. Ichthyoplankton spatial distribution and its relation with water column stratification in fjords of southern Chile $\left(46^{\circ} 48^{\prime}-50^{\circ} 09^{\prime} \mathrm{S}\right)$ in austral spring 1996 and 2008. Continental Shelf Research 31: 293-303.

Colman JA. 1995. Biology and fisheries of New Zealand hake (M. australis). In: Alheit J \& TJ Pitcher (eds). Hake: Fisheries, ecology, and markets, pp. 365-388. Chapman and Hall, London.

Espe M, K Ruohonen \& A El-Mowafi. 2012. Effect of taurine supplementation on the metabolism and body lipid-toprotein ratio in juvenile Atlantic salmon (Salmo salar). Aquaculture Research 43: 349-360. 
Fallah AA, SS Saei-Dehkordi \& A Nematollahi. 2011. Comparative assessment of proximate composition, physicochemical parameters, fatty acid profile and mineral content in farmed and wild rainbow trout (Oncorhynchus mykiss). International Journal of Food Science \& Technology 46: 767-773.

Folch J, M Lees \& GHS Stanley. 1957. A simple method for the isolation and purification of total lipids from animal tissue. Journal of Biological Chemistry 226: 497-509.

Fuentes A, I Fernandez-Segovia, JA Serra \& JM Barat. 2010. Comparison of wild and cultured sea bass (Dicentrarchus labrax) quality. Food Chemistry 119: 1514-1518.

Glencross BD. 2009. Exploring the nutritional demand for essential fatty acids by aquaculture species. Reviews in Aquaculture 1: 71-124.

Gonzalez S, GJ Flick, SF O'Keefe, SE Duncan, E McLean \& SR Craig. 2006. Composition of farmed and wild yellow perch (Perca flavescens). Journal of Food Composition and Analysis 19: 720-726.

Grisdale-Helland B, A Lemme \& SJ Helland. 2013. Threonine requirement for maintenance and efficiency of utilization for threonine accretion in Atlantic salmon smolts determined using increasing ration levels. Aquaculture 372/375: 158-166.

Guisande C, I Riveiro, A Sola \& L Valdes. 1998. Effect of biotic and abiotic factors on the biochemical composition of wild eggs and larvae of several fish species. Marine Ecology Progress Series 163: 53-61.

Iglesias J, MJ Lago, FJ Sánchez \& R Cal. 2010. Capture, transport and acclimatization to captivity of European hake, Merluccius merluccius L: preliminary data on feeding and growth. Aquaculture Research 41: 607-609.

Izquierdo MS, H Fernandez-Palacios \& AGJ Tacon. 2001. Effect of broodstock nutrition on reproductive performance of fish. Aquaculture 197: 25-42.

Jankowska B, Z Zakęś, T Żmijewski \& M Szczepkowski. 2008. Fatty acid composition of wild and cultured northern pike (Esox lucius). Journal of Applied Ichthyology 24: 196-201.

Johnston IA, X Li, VLA Vieira, D Nickell, A Dingwall, R Alderson, P Campbell \& R Bickerdike. 2006. Muscle and flesh quality traits in wild and farmed Atlantic salmon. Aquaculture 256: 323-336.

Morrison W \& L Smith. 1964. Preparation of fatty acid methyl esters and dimethylacetals from lipids with boron-fluoride methanol. Journal of Lipid Research 5: 600-608.

Niklitschek EJ, D Soto, A Lafon, C Molinet \& P Toledo. 2013. Southward expansion of the Chilean salmon industry in the Patagonian Fjords: main environmental challenges. Reviews in Aquaculture 5: 172-195.
Norambuena F, A Estevez, G Bell, I Carazo \& N Duncan. 2012. Proximate and fatty acid compositions in muscle, liver and gonads of wild versus cultured broodstock of Senegalese sole (Solea senegalensis). Aquaculture 356: 176-185.

Paya I. 1992. The diet of Patagonian hake Merluccius australis polylepis and its daily ration of Patagonian grenadier Macrouronus magellanicus. South African Journal of Marine Science 12: 753-760.

Sağglık S, M Alpaslan, T Gezgin, K Çetintürkc, A Tekinay \& KC Güven. 2003. Fatty acid composition of wild and cultivated gilthead seabream (Sparus aurata) and sea bass (Dicentrarchus labrax). European Journal of Lipid Science and Technology 105: 104-107.

Sánchez FJ, R Cal, JJ Otero, MJ Lago, C Gómez \& J Iglesias. 2012. The first spontaneous spawning of European hake Merluccius merluccius L: characteristics of eggs and early larval stages. Aquaculture Research 43: 1729-1733.

Shearer KD. 1994. Factors affecting the proximate composition of cultured fishes with emphasis on salmonids. Aquaculture 119: 63-88.

Silva K. 2011. Estado de potenciales especies para diversificar la acuicultura. Mundo Acuicola 82: 6-8.

Sylvia G. 1995. Global markets and products of hake. In: Alheit J \& TJ Pitcher (eds). Hake: Fisheries, ecology, and markets, pp. 415-435. Chapman and Hall, London.

Tingley GA, LV Purchase, MV Bravington \& SJ Holden. 1995. Biology and fisheries of hakes (M. hubbsi and $M$. australis) around the Falkland Islands. In: Alheit J \& TJ Pitcher (eds). Hake: Fisheries, ecology, and markets, pp. 269-303. Chapman and Hall, London.

Wang F, X Ma, W Wang \& J Liu. 2012. Comparison of proximate composition, amino acid and fatty acid profiles in wild, pond- and cage-cultured longsnout catfish (Leiocassis longirostris). International Journal of Food Science \& Technology 47: 1772-1776.

Wurmann CF. 2007. Salmon farming in Chile: History, policies, and development strategies. In: Leung P, CS Lee \& PJ O'Bryen (eds). Species and system selection for sustainable aquaculture, pp. 415-444. Blackwell Publishing, Oxford.

Yildiz M, E Şener \& M Timur. 2008. Effects of differences in diet and seasonal changes on the fatty acid composition in fillets from farmed and wild sea bream (Sparus aurata L.) and sea bass (Dicentrarchus labrax L.). International Journal of Food Science \& Technology 43: 853-858.

Received 5 December 2019 and accepted 10 July 2020

Editor: Claudia Bustos D. 